\title{
HUBUNGAN KETERLIBATAN DALAM ORGANISASI BADAN (BEM) DENGAN KETERAMPILAN BERPIKIR KRITIS DAN SIKAP DEMOKRATIS MAHASISWA
}

\author{
Khristoforus Palli Ngongo ${ }^{1)}$ Abdul Gafur ${ }^{2)}$ \\ Pendidikan Pancasila dan Kewarganegaraan PPs UNY, PPs Universitas Negeri Yogyakarta2) \\ pallipoti@yahoo.com ${ }^{1)}$, agafur68@gmail.com²
}

\begin{abstract}
Abstrak
Penelitian ini bertujuan untuk mengetahui: (1) hubungan antara keterlibatan dalam organisasi BEM dengan keterampilan berpikir kritis, (2) hubungan antara keterlibatan dalam organisasi dengan sikap demokratis, dan (3) hubungan antara keterampilan berpikir kritis dan sikap demokratis mahasiswa STKIP Weetebula. Penelitian ini merupakan penelitian korelasi. Jumlah populasi 30 orang pengurus BEM STKIP Weetebula. Data diperoleh melalui penyebaran angket pada 30 mahasiswa tentang keterlibatan organisasi dan sikap demokratis, serta angket observasi untuk mengetahui keterampilan berpikir kritis. Teknik analisis data yang digunakan adalah analisis korelasi. Uji hipotesis adalah uji parametric dengan rumus korelasi product moment untuk menguji hubungan antara variabel, yaitu keterlibatan dalam organisasi dengan keterampilan berpikir kritis dan sikap demokratis. Hasil penelitian menunjukan bahwa terdapat hubungan yang signifikan antara: (1) keterlibatan organisasi dengan keterampilan berpikir kritis. (2) keterlibatan organisasi dengan sikap demokratis. (3) keterampilan berpikir kritis dengan sikap demokratis. Berdasarkan hasil analisis tersebut maka keterlibatan mahasiswa STKIP Weetebula dalam organisasi BEM memiliki hubungan yang signifikan dengan keterampilan berpikir kritis dan sikap demokratis.

Kata kunci: keterlibatan organisasi, keterampilan berpikir kritis dan sikap demokratis mahasiswa
\end{abstract}

\section{THE RELATIONSHIP BETWEEN THE INVOLVEMENT IN THE ORGANIZATION OF STUDENTS' EXECUTIVE BODY AND THE CRITICAL THINKING SKIILS AND DEMOCRATIC ATTITUDES OF STUDENTS}

\author{
Khristoforus Palli Ngongo ${ }^{1)}$ Abdul Gafur ${ }^{2)}$ \\ Pendidikan Pancasila dan Kewarganegaraan PPs UNY, PPs Universitas Negeri Yogyakarta2) \\ pallipoti@yahoo.com ${ }^{1)}$, agafur68@gmail.com²)
}

\begin{abstract}
This study aims to find out the relationship: (1) between the involvement in the organization of SEB and the critical thinking skills, (2) between the involvement in the organization of SEB and their democratic attitudes, and (3) between the critical thinking skills and their democratic attitudes. This research was a correlational study using the quantitative approach. It was a population study; the population comprised 30 students who were board members of SEB of STKIP Weetebula. The data were collected by distributing questionnaires on the involvement in the organizations and democratic attitudes to 30 students and those on their critical thinking skills to several lecturers. The data analysis technique was the correlation technique. The hypothesis testing employed a parametric test using the product moment correlation formula. The results of the study are as follows. (I) There is a significant positive relationship between the involvement in the organization of SEB and the critical thinking skills. (2) There is a significant positive relationship between the involvement in the organization of SEB and the democratic attitudes of students. (3) There is a significant positive relationship between the critical thinking skills and the democratic attitudes. Based on the analysis finding, the result show that the involvement in the organization of students' executive body has significant positive relationship with the critical thinking skills and democratic attitudes of students of STKIP Weetebula of the regency of Sumba Barat Daya).
\end{abstract}

Keywords: involvement in organization, students' critical thinking skills and democratic attitudes 


\section{Pendahuluan}

Tujuan pendidikan adalah memanusiakan manusia (humanisasi). Tujuan pendidikan ini sangat mulia, karena itu, maka Paulo Freire menyebut pendidikan itu membebaskan atau dalam bahasa Mudji sebagai jalan menuju peradaban (Sutrisno, 2013, p. 11). Tujuan pendidikan yang mulia ini harus pula diikuti suatu proses pendidikan yang membebaskan dengan cara mengemas suatu proses pendidikan yang menyenangkan dengan menciptakan berbagai model dan metode pembelajaran agar peserta didik yang sedang dalam proses pendidikan merasa berada dalam perjalanan menuju pembebasan. Tidak ada tujuan pendidikan yang membebaskan jika prosesnya terpenjara.

Setiap negara di dunia telah merumuskan tujuan pendidikan nasionalnya dalam konstitusi di negaranya agar dapat mengantarkan seluruh warga negaranya keluar dari penjajahan yaitu ketidaktahuan (kebodohan) yang telah menciptakan ruang kemiskinan dan penindasan. Usaha-usaha menanamkan harapan kepada warga negara dirumuskan dengan baik dan terencana dalam tujuan pendidikan nasional negara tersebut. Begitupun tujuan pendidikan nasional Indonesia telah dirumuskan sedemikian rupa untuk mencapai kesejahteraan warga negara. Tujuan dan fungsi pendidikan dirumuskan dalam Undang-Undang Sistem Pendidikan Nasional Nomor 20 Tahun 2003 yaitu pendidikan nasional berfungsi mengembangkan kemampuan dan membentuk watak serta peradaban bangsa yang bermartabat dalam rangka mencerdaskan kehidupan bangsa dan bertujuan untuk berkembangnya potensi peserta didik agar menjadi manusia yang beriman dan bertakwa kepada Tuhan Yang Maha Esa, berakhlak mulia, sehat, berilmu, cakap, kreatif, mandiri, mencapai warga negara yang demokratis, kritis terhadap perkembangan Ilmu Pengetahuan dan Teknologi (IPTEK) serta bertanggung jawab terhadap dirinya, lingkungan, bangsa dan negaranya (Pasal 3) (Depdiknas, 2003).

Mencapai warga negara yang peka terhadap perkembangan IPTEK dan memiliki kemampuan dalam pergaulan internasional dibutuhkan keterampilan berpikir kritis dan sikap demokratis. Keterampilan berpikir kritis diperlukan untuk menelaah secara kritis terhadap segala fenomena global yang masuk dan mempengaruhi warga negara, dalam bahasa Georgi Lozanov sebagai kesulitan manusia yang luar biasa (Robinson, 2005, p. 1) yang dihadapi warga negara muda saat ini. Sedangkan sikap demokratis diperlukan agar warga negara mampu menyesuaikan diri, bersikap toleran, terbuka terhadap dinamika pluralisme baik pemikiran, identitas suku, ras, agama maupun terhadap identitas kebangsaan yang berbeda.

Mencapai generasi warga negara yang memiliki keterampilan berpikir kritis dan sikap demokratis adalah salah satu tujuan pendidikan nasional. Warga negara yang demokratis adalah warga negara yang memiliki sikap demokratis. Memiliki keterampilan berpikir kritis, atau kemampuan berpikir yang terampil bisa membangun pribadi individu yang demokratis. Karena tidak terbiasa berpikir terbuka misalnya, potensial akan melahirkan konflik dengan orang lain. Orang-orang yang tidak terlatih dengan kemampuan berpikir yang baik, akan memosisikan dirinya sebagai pemilik pemikiran yang paling baik, dan menganggap orang lain, pemilik kemampuan berpikir yang buruk. Segaimana yang disampaikan Sudarman (2013, p. 35) bahwa orang yang tidak terbiasa berdiskusi, atau berdebat, atau dialog, akan menganggap dirinya adalah pemilik pemikiran yang paling baik.

Salah satu isu yang sangat hangat dalam perbincangan global adalah isu demokrasi. Tema ini tidak lagi hanya sekedar perbincangan para politisi yang pada masa lampau dianggap adalah konsep elit dan hanya milik mutlak mereka, sekarang telah memasuki ruang-ruang privat seperti keluarga. Konsep-konsepnya menjadi sangat universal dan dapat saja berdampak negatif terhadap kelangsungan hidup keluarga, karena konsep Barat tidak tersaring oleh tradisi suatu negara. Sebagai contoh konsep demokrasi liberal, kebebasan individu sangat diagungkan, lalu setiap anak Indonesia menuntut seperti itu, hal ini justru merusak tatanan filosofi berdemokrasi Indonesia yang lahir dan berkembang dari karakteristik masyarakat gotong-royong. Bahkan konsep invidualisme yang merupakan salah satu ciri demokrasi liberal menyusup dalam konsep Pendidikan Kewarganegaraan Asia (termasuk Indonesia), sebagaimana yang disebutkan Oleh Kennedy dan Fairbrother yang mengungkapkan bahwa Pendidikan Kewarganegaraan Asia lebih ditandai oleh nilai- 
nilai personal daripada nilai-nilai publik dan kewarganegaraan (Samsuri, 2013, p. 2). Oleh sebab itu menurut Fadhilah \& Nuraina (2011, p. 46) terbentuknya demokrasi dan perkembangannya di Indonesia harus diperkuat dengan faktor internal dari bangsa Indonesia sendiri yaitu demokrasi yang bersumber dari nilai budaya dan ideologi politik Indonesia.

Sajian gagasan-gagasan demokrasi semacam itu tidak diterima begitu saja melainkan penting untuk difilter untuk melihat, membaca, mengolah, mengevaluasi secara mendalam, menarik kesimpulan dan kemudian mengambil sikap yang bermanfaat bagi kehidupan sebagai bangsa. Proses ini membutuhkan keterampilan berpikir kritis. Demikian penting berpikir kritis, setelah tahun 1948 konvensi dari American Psychological Association, berpikir kritis telah menjadi isu penting dalam pendidikan selama bertahun-tahun (Schneider, 2012, p. 1). Pada tempat yang berbeda, Presiden Amerika Serikat Barac Obama, seperti dikutip oleh majalah The Critical Thinking Community (2009) menyeruhkan pemikiran kritis dikembangkan di sekolahsekolah di Amerika. Siswa tidak hanya dilihat dari kemampuan mengisi melingkari soal-soal tes tetapi mereka harus memiliki keterampilan pada abad ke-21 seperti kemampuan memecahkan masalah, berpikir kritis. Berpikir kritis berbeda dengan berpikir tidak kritis yang langsung mengarah pada kesimpulan menerima atau tidak menerima tanpa sungguhsungguh mempertimbangkan data yang melatarbelakangi sebuah kesimpulan yang akan diambil. Berpikir kritis menuntut intreprestasi dan evaluasi terhadap observasi, komunikasi, dan sumber-sumber informasi lainnya (Fisher, 2009, p. 13)

Pemikiran kritis yang baik akan memenuhi standar intelektual, seperti kejelasan, relevansi, kecukupan, koherensi. Berpikir kritis juga menuntut keterampilan dalam memikirkan asumsi-asumsi, dalam mengajukan pertanyaan-pertanyaan terhadap konsep demokrasi yang diwacanakan sebelum menjadi pilihan untuk dikembangkan menjadi cara hidup bersama sebagai sebuah bangsa.

Keterampilan berpikir kritis dan sikap demokratis tidak muncul begitu saja. Keterampilan berpikir kritis dan sikap demokratis adalah hasil dari sebuah proses pendidikan. Di banyak negara kebutuhan pendidikan demokrasi di sekolah untuk membentuk sikap de- mokrasi warga negara menjadi hal yang penting dan mendesak sebagai solusi dari masalah dunia modern saat ini (Şanlı \& Altun, 2015, p. 2). Selanjutnya dalam tulisan Sanlı \& Yesil menyebutkan bahwa, salah satu tujuan pendidikan demokrasi adalah untuk menbentuk keterampilan berpikir, menyatakan pikiran secara bebas, rapih, singkat dan menghormati pikiran orang lain (Şanlı \& Altun, 2015, p. 3).

Pasal 13 (1) Undang-Undang Nomor 20 Tahun 2003 tentang Sistem Pendidikan Nasional disebutkan bahwa "Jalur pendidikan terdiri atas pendidikan formal, nonformal, dan informal yang dapat saling melengkapi dan memperkaya" (Depdiknas, 2003). Artinya, proses pendidikan tidak hanya terjadi dalam ruang-ruang formal pendidikan dengan perangkat kurikulum yang serba ketat dan sangat kaku melainkan dapat berlangsung di luar kelas seperti dalam kegiatan ekstrakurikuler. Dalam Undang-Undang Nomor 12 Tahun 2012 tentang Pendidikan Tinggi (Presiden Republik Indonesia, 2012) menyebutkan bahwa kegiatan ekstrakurikuler dapat dilaksanakan melalui organisasi kemahasiswaan (pasal 14). Ruang ekstrakurikuler tersebut yang tersedia di perguruan tinggi salah satunya organisasi mahasiswa seperti Badan Eksekutif Mahasiswa.

Pendidikan nonformal diperlukan dan didukung selama pendidikan tersebut dalam visi/misinya dalam rangka mendukung pendidikan sepanjang hayat, dan penekanan pada penguasaan pengetahuan dan keterampilan fungsional serta pengembangan sikap dan kepribadian profesional warga negara (Depdiknas, 2003).

Badan Eksekutif Mahasiswa (BEM) dapat dimanfaatkan oleh mahasiswa untuk bertumbuhnya warga negara yang kritis yang mampu memecahkan berbagai persoalan kehidupan berbangsa dan bernegara seperti persoalan demokrasi yang semakin hari menyajikan gaya atau tatacara berdemokrasi. Kendati terdapat suara sinis terhadap demokrasi saat ini (Perwita, 2005), namun harus diakui bahwa perkembangan materi dan gerakannya dapat ditemukan dampak positifnya bagi masyarakat sebagai aktor utama yang disasar untuk disejahterakan dalam sebuah rezim demokrasi. Pememilihan kepala daerah secara langsung dan serempak adalah contoh nyata yang dapat kita lihat bahwa demokrasi sedang berkembang. 
Menemukan dan melaksanakan konsep berdemokrasi yang pertama dan terbesar semacam ini tentunya adalah buah dari keterampilan berpikir kritis anak-anak bangsa yang dulunya adalah seorang mahasiswa. Namun tidak serta merta dapat disimpulkan bahwa seluruh mahasiswa yang kuliah di suatu perguruan tinggi memiliki keterampilan berpikir kritis dan sikap demokratis yang baik sebagaimana yang diharapkan.

Hasil pengamatan peneliti beberapa tahun (2010-2014) selama peneliti bekerja pada Sekolah Tinggi Keguruan dan Ilmu Pendidikan (STKIP) Weetebula, mahasiswa memperlihatkan keterampilan berpikir yang kurang kritis dan sikap yang kurang demokratis. Berpikir yang kurang kritis misalnya; mahasiswa cenderung menerima informasi, mengambil kesimpulan dan kemudian langsung meneruskan kepada orang lain tanpa terlebih dahulu mengolah, mengevaluasi, menelusuri fakta. Dampaknya tidak jarang menimbulkan pertengkaran diantara mereka yang secara implisit melorotkan paradigma masyarakat umum akan identitas mahasiswa sebagai cendikiawan atau kandidat cendikiawan, agen perubahan. Selain itu, dalam pengamatan awal peneliti, menyaksikan sikap kurang demokratis seperti kurang menghargai perbedaan (masih mempelihatkan ego kesukuan) dalam kelas, memaksakan kehendak, dan cenderung anarkis dalam bertindak.

Berdasarkan uraian yang telah disampaikan tersebut, maka penelitian ini bertujuan untuk mengetahui: (1) hubungan antara keterlibatan dalam organisasi BEM dengan keterampilan berpikir kritis, (2) hubungan antara keterlibatan dalam organisasi dengan sikap demokratis, dan (3) hubungan antara keterampilan berpikir kritis dan sikap demokratis mahasiswa STKIP Weetebula.

\section{Metode}

Penelitian ini merupakan penelitian korelasi. Bertujuan untuk menemukan ada tidaknya hubungan antara keterlibatan organisasi dengan keterampilan berpikir kritis dan sikap demokratis pada mahasiswa STKIP Weetebula, Kabupaten Sumba Barat Daya, Nusa Tenggara Timur.

Penelitian ini dilaksanakan di STKIP Weetebula, Kabupaten Sumba Barat Daya, Provinsi Nusa Tenggara Timur. Penelitian ini dimulai dari bulan April sampai dengan Mei 2016.

Populasi merupakan wilayah generalisasi yang terdiri atas objek atau subjek yang mempunyai kualitas dan karakteristik tertentu yang ditetapkan oleh peneliti untuk dipelajari dan kemudian ditarik kesimpulan (Sugiyono, 2010, p. 117). Populasi dalam penelitian ini adalah mahasiswa STKIP Weetebula yang ikut dalam organisasi BEM. Total jumlah populasi adalah 30 orang mahasiswa. Sampel diambil sama dengan populasi. Sampel dalam penelitian ini adalah mahasiswa yang ikut dalam kepengurusan BEM. Jumlah sampel adalah berjumlah 30 orang yang merupakan keseluruhan dari total populasi penelitian.

Adapun variabel bebas atau independent variable dalam penelitian ini adalah keterlibatan dalam organisasi BEM (X). Variabel terikat dalam penelitian ini adalah keterampilan berpikir kritis $\left(\mathrm{Y}_{1}\right)$ dan sikap demokratis $\left(\mathrm{Y}_{2}\right)$.

Teknik pengumpulan data yang digunakan dalam penelitian ini adalah dokumentasi, observasi, kuesioner berupa angket. dokumentasi digunakan untuk mendapatkan data awal mengenai jumlah dan nama seluruh pengurus BEM STKIP Weetebula. Observasi dipergunakan khusus untuk memperoleh data terkait dengan variabel keterampilan berpikir kritis. Larry Cristensen (2004) menyatakan bahwa "Observation is an important way of collecting information about people because people do not always do what they say do". Observasi merupakan cara yang penting untuk mendapatkan informasi yang pasti tentang orang, karena apa yang dikatakan orang belum tentu sama dengan apa yang dikerjakan (Sugiyono, 2013, pp. 196-197).

Dari segi proses pelaksanaan pengumpulan data, Sugiyono (2013, pp. 197198) membedakan observasi menjadi observasi berperan serta (partisipant observation) dan non parstisipant observation. Partisipant observaton adalah observasi dimana peneliti terlibat langsung dalam kegiatan sehari-hari dengan orang yang sedang diamati atau yang digunakan sebagi sumber data. Observasi non parstisipant observation adalah peneliti tidak terlibat langsung dalam aktivitas orang-orang yang sedang diamati. Observasi dari segi instrumentasi yang digunakan, maka observasi dapat dibedakan menjadi observasi terstruktur dan observasi tidak terstruktur. 
Observasi terstruktur adalah observasi yang telah dirancang secara sistematis, tentang apa yang akan diamati, kapan dan di mana tempatnya. Dalam melakukan pengamatan, peneliti menggunakan istrumen penelitian yang telah teruji validitas dan reliabilitasnya. Angket tertutup dapat juga digunakan sebagai pedoman untuk melakukan observasi. Sedangkan observasi tidak terstruktur adalah observasi yang tidak dipersiapkan secara sistematis tentang apa yang akan diobservasi.

Terkait dengan penelitian ini, peneliti menggunakan teknik observasi non partisipant dengan instrumen berupa lembar observasi. Observasi dibantu oleh 6 orang dosen yang mengajar pada 4 program studi (PGSD, Bahasa dan Sastra Indonesia, Matematika, dan Fisika) dimana para responden kuliah/belajar. Peneliti memberikan instrumen observasi kepada 6 orang dosen. Setiap dosen mengamati masing-masing 5 orang mahasiswa (responden). Hal ini dilakukan oleh peneliti atas pertimbangan bahwa 6 dosen tersebut mengenal responden dan aktivitas (pada saat kuliah berjalan) responden di kelas. Teknik kuesioner merupakan teknik pengumpuan data yang dilakukan dengan cara memberikan seperangkat pertanyaan atau pernyataan tertulis kepada responden (mahasiswa) untuk dijawabnya. Teknik kuesioner dilakukan untuk memperoleh data yang berkaitan dengan variabel keterlibatan organisasi dan sikap demokratis.

Uji validitas atau kesahihan digunakan untuk mengetahui seberapa tepat suatu alat ukur mampu melakukan fungsi pengukuran. Menurut Sugiyono (2012, p. 123) suatu instrumen non-tes yang digunakan untuk mengukur sikap atau persepsi harus memenuhi syarat validitas konstruk yaitu pengujian instrumen untuk melihat kesesuaian konstruk butir instrumen. Hal ini dilaksanakan melalui pertimbangan ahli atau yang sering disebut dengan validitas ahli yang bertujuan untuk melihat konstruk logis setiap butir terhadap variabel yang dijelaskan dan keterpahaman setiap butir pertanyaan atau pernyataan. Setelah instrumen yang diajukan oleh peneliti mendapat persetujuan dari para ahli (validator), selanjutnya instrumen tersebut dilakukan uji coba empiris. Uji coba empiris dari instrumen oleh peneliti dilakukan pada 30 orang mahasiswa yang tidak termasuk dalam sampel penelitian.
Data yang diperoleh dari uji coba empiris, selanjutnya dilakukan analisis dengan menggunakan analisis item yaitu menguji valid tidaknya setiap item pertanyaan atau pernyataan dalam instrumen angket dan instrumen observasi. Analisis item dilakukan dengan menghitung korelasi antara skor butir instrumen dengan skor total. Untuk menganalisis item dapat menggunakan rumus korelasi product moment pearson (Arikunto, 2010, p. 213) berikut ini:

$$
r x y=\frac{\mathrm{N} \sum \mathrm{XY}-\left(\sum \mathrm{X}\right)\left(\sum \mathrm{Y}\right)}{\sqrt{[\mathrm{N}} \sum \mathrm{X}}
$$

\section{Keterangan:}

rxy : Koefesien korelasi tiap butir pertanyaan

$\mathrm{N} \quad$ : Jumlah anggota sampel

$\sum \mathrm{X}:$ Jumlah skor tiap butir pertanyaan

$\sum \mathrm{Y}$ : Jumlah skor total

$\sum X Y$ : Jumlah hasil kali X dan $Y$

$\sum X^{2}$ : Jumlah kuadrat skor tiap butir pertanyaan

$\sum \mathrm{Y}^{2}:$ Jumlah kuadrat skor total

Nilai koefesien korelasi (r), dihitung dengan menggunakan bantuan program komputer yaitu SPSS for windows versi 16.0. Setelah nilai (r) diperoleh maka dilanjutkan dengan konsultasi $r$ tabel pada taraf signifikansi $5 \%$. Jika $r$ hitung sama dengan atau lebih dari $r$ tabel maka butir instrumen dapat dikatakan valid. Demikian sebaliknya, yaitu jika r hitung kurang dari $r$ tabel maka butir instrumen dapat dikatakan tidak valid.

Hasil uji coba instrumen uji validitas angket keterlibatan organisasi BEM dapat disimpulkan bahwa dari 17 item, 1 item tidak valid dan 16 item adalah valid. Hasil uji validitas keterampilan berpikir kritis dapat disimpulkan bahwa dari 4 item pernyataan untuk angket keterampilan berpikir kritis mahasiswa, semua item adalah valid. Dan hasil uji validitas dapat disimpulkan bahwa dari 24 item pernyataan untuk angket sikap demokratis mahasiswa, 2 item tidak valid dan 22 item adalah valid.

Setelah melakukan pengujian validitas, suatu instrumen mesti diuji juga reliabilitasnya. Uji reliabilitas digunakan untuk mengetahui konsistensi alat ukur, apakah alat 
pengukur yang digunakan dapat diandalkan dan tetap konsisten jika pengukuran tersebut diulangi. Hasil uji reliabilitas menentukan dan mencerminkan, apakah dapat dipercaya atau tidaknya suatu instrumen penelitian berdasarkan tingkat kemantapan dan ketepatan suatu alat ukur.

Uji reliabilitas instrumen dilakukan dengan menggunakan metode AlphaCronbach. Menurut Kountur (2009, p. 168) "Cronbach Alpha $(\alpha)$ merupakan teknik pengujian reliabilitas suatu istrumen berupa kuesioner untuk mengukur laten variabel yang paling sering digunakan karena dapat digunakan pada kuesioner yang jawaban atau tanggapannya lebih dari dua pilihan."

Pemilihan metode ini disesuaikan dengan instrumen pengumpulan data yang berupa instrumen non-tes yaitu angket dengan alternative jawaban 1-4. Perhitungan dilakukan dengan bantuan SPSS for windows versi 16.0. Reliabilitas diukur dengan skala Alpha $0-1$. Instrumen penelitian dapat dikatakan memiliki tingkat reliabilitas yang memadai jika koefisien Alpha Cronbach sama dengan atau lebih besar dari nilai kritis 0,7 .

Tabel 1. Hasil Uji Reliabilitas Data

\begin{tabular}{llll}
\hline \multicolumn{1}{c}{ Variabel } & $\begin{array}{l}\text { Cronbach's } \\
\text { Alpha }\end{array}$ & $\begin{array}{l}\text { Nilai } \\
\text { Kritis }\end{array}$ & $\begin{array}{l}\text { Ketera- } \\
\text { ngan }\end{array}$ \\
\hline $\begin{array}{l}\text { Keterlibatan } \\
\text { Organisasi BEM }\end{array}$ & 0,884 & 0,7 & Reliable \\
$\begin{array}{l}\text { Keterampilan } \\
\text { Berpikir Kritis } \\
\text { Sikap Demokratis }\end{array}$ & 0,789 & 0,7 & Reliable \\
\hline
\end{tabular}

Berdasarkan data pada tabel 1, perhitungan realibilitas tersebut di atas dapat diketahui bahwa nilai reliabilitas pada angket keterlibatan organisasi BEM adalah 0,884. Untuk melihat apakah instrument tersebut reliable atau tidak, maka digunakan nilai kritis 0,7

Jika Cronbach's Alpha > nilai kritis, maka instrument yang digunakan ialah $r e$ liable. Dengan demikian nilai Cronbach's Alpha > nilai kritis atau 0,884>0,7. Maka instrument untuk keterlibatan organisasi BEM yang digunakan dinyatakan reliable.

Demikian dengan keterampilan berpikir kritis dapat dilihat bahwa nilai Cronbach's Alpha > nilai kritis atau 0,789>0,7. Maka instrument untuk keterampilan berpikir kritis yang digunakan dinyatakan reliable. Selanjutnya dapat dilihat dari tabel sikap demokratis yang menunjukan bahwa nilai Cronbach's Alpha > nilai kritis atau 0,854 > 0,7. Maka instrument untuk sikap demokratis yang digunakan dinyatakan reliable.

Teknik analisis data yang digunakan dalam penelitian ini adalah analisis korelasi. Analisis deskriptif digunakan untuk memberikan gambaran atau kejelasan pada setiap variabel. Sedangkan analisis linear digunakan untuk mengetahui hubungan antar variabel. Uji persyaratan analisis tersebut adalah uji normalitas dan uji linearitas.

Uji normalitas adalah untuk mengetahui normal atau tidaknya sebaran data yang akan dianalisis. Uji normalitas sebaran data penelitian dilakukan dengan teknik Kolmogorov-Smirnov. Suatu sebaran dikatakan normal apabila skor $\mathrm{P}$ lebih besar dari 0,05. Sebaliknya, suatu sebaran dikatan tidak normal apabila skor P lebih kecil dari 0,05. Rangkuman dari perhitungan data untuk uji normalitas, menunjukkan bahwa data keterlibatan dalam organisasi BEM, keterampilan berpikir kritis dan data sikap demokratis berdistribusi normal yang ditunjukkan pada Tabel 2.

Tabel 2. Hasil Uji Normalitas Data

\begin{tabular}{lllll}
\hline No & Variabel & $\begin{array}{l}\text { Nilai } \\
\text { Asymp. Sig } \\
\text { (2-tailed) }\end{array}$ & $\begin{array}{l}\text { Taraf } \\
\text { Signifi- } \\
\text { kansi }\end{array}$ & $\begin{array}{l}\text { Keputu } \\
\text { s-an }\end{array}$ \\
\hline 1 & $\begin{array}{l}\text { Keterlibatan } \\
\text { organisasi }\end{array}$ & 0,963 & 0,05 & Normal \\
2 & $\begin{array}{l}\text { Keterampilan } \\
\text { Berpikir kritis }\end{array}$ & 0,607 & 0,05 & Normal \\
3 & $\begin{array}{l}\text { Sikap sikap } \\
\text { demokratis }\end{array}$ & 0,619 & 0,05 & Normal \\
\hline
\end{tabular}

\section{Hasil dan Pembahasan}

Uji Hipotesis.

Uji hipotesis dalam penelitian ini menggunakan analisis korelasi Product moment untuk mengetahui hubungan keterlibatan organisasi terhadap keterampilan berpikir kritis dan sikap demokratis pada mahasiswa STKIP Weetebula.

Variabel yang diteliti dalam penelitian ini adalah hubungan antara keterlibatan dalam organisasi BEM (X), keterampilan ber- 
pikir kritis $\left(\mathrm{Y}_{1}\right)$ dan sikap demokratis $\left(\mathrm{Y}_{2}\right)$. Teknik analisis data yang digunakan dalam penelitian ini adalah uji korelasi Product moment. Uji koefisien bertujuan untuk menghubungkan variabel bebas dan variabel terikat. Demikian uji koefisien digunakan dalam penelitian untuk menguji hubungan keterlibatan dalam organisasi BEM $(\mathrm{X})$ yang merupakan variabel bebas dengan dua variabel terikat yaitu keterampilan berpikir kritis $\left(\mathrm{Y}_{1}\right)$ dan sikap demokratis $\left(\mathrm{Y}_{2}\right)$.

Setelah tahap pengujian kualitas data yaitu menguji validitas dan reliabilitas instrumen dilakukan, maka selanjutnya pelaksanaan penelitian (pengambilan data) dilakukan. Setelah data didapat, maka tahap selanjutnya ialah melakukan pengujian hipotesis. Pengujian hipotesis dilakukan untuk mengetahui apakah hipotesis yang diungkapkan dalam penelitian ini diterima atau ditolak. Berdasarkan uji prasyarat yang ditentukan untuk pengujian hipotesis, seperti uji normalitas dan uji linearitas dari data yang diperoleh telah dipenuhi. Dalam menguji hipotesis ini, maka digunakan uji parametric dengan menggunakan rumus korelasi Product moment dengan bantuan program perhitungan SPSS versi 16.0. Untuk dapat mengetahui kuat lemahnya tingkat atau derajat keeratan hubungan antara variabel-variabel yang diteliti, maka digunakan tabel kriteria pedoman untuk koefisien korelasi sesuai dengan pendapat Sugiyono (2008, p. 257).

Tabel 3. Pedoman Interpretasi Koefisien Korelasi

\begin{tabular}{ll}
\hline Interval Koefisien & Tingkat Hubungan \\
\hline $0,00-0,199$ & Sangat Rendah \\
$0,20-0,399$ & Rendah \\
$0,40-0,599$ & Kuat \\
$0,60-0,799$ & Sedang \\
$0,80-1,00$ & Sangat Kuat \\
\hline
\end{tabular}

Hasil Uji Hipotesis Pertama yaitu Korelasi antara Keterlibatan dalam Organisasi BEM (X) dengan Keterampilan Berpikir Kritis $\left(\mathrm{Y}_{1}\right)$

Data hasil pengukuran tingkat huungan antara variabel keterlibatan dalam organisasi BEM (X) dengan keterampilan berpikir kritis (Y1) mahasiswa dapat dilihat dalam Tabel 4.
Tabel 4. Korelasi antara Keterlibatan dalam Organisasi BEM (X) dengan Keterampilan Berpikir Kritis( $\left.\mathrm{Y}_{1}\right)$

\begin{tabular}{llll}
\hline \multicolumn{1}{c}{ Variabel } & $\mathrm{R}$ & $\mathrm{Sig}$ & $\mathrm{N}$ \\
\hline Keterlibatan dalam & 0,667 & 0,000 & 30 \\
organisasi BEM $(\mathrm{X})$ & & & \\
dan keterampilan & & & \\
berpikir kritis $\left(\mathrm{Y}_{1}\right)$ & & & \\
\hline
\end{tabular}

Berdasarkan perhitungan yang ditunjukan pada tabel 4 diperoleh nilai koefisiensi korelasi 0,667 pada tingkat taraf kepercayaan 0,05 atau $95 \%$.

Dari hasil perhitungan diperoleh nilai signifikansi sebesar $0,000<\alpha(0,05)$ maka hipotesis kerja $\mathrm{H}_{1}$ diterima. Artinya terdapat hubungan yang signifikan antar keterlibatan dalam organisasi BEM $(\mathrm{X})$ dengan keterampilan berpikir kritis $\left(\mathrm{Y}_{1}\right)$. Tingkat hubungan antara variabel keterlibatan dalam organisasi BEM (X) dengan varibel keterampilan berpikir kritis $\left(\mathrm{Y}_{1}\right)$ termasuk dalam kategori kuat (0,60-799) karena nilai korelasi yang diperoleh dari hasil uji korelasi antara variabel $\mathrm{X}$ dengan variabel $\mathrm{Y}_{1}$ sebesar 0,667.

Hasil Uji Hipotesis Kedua yaitu Korelasi antara Keterlibatan dalam Organisasi BEM (X) dengan Sikap Demokratis $\left(\mathrm{Y}_{2}\right)$.

Data hasil pengukuran tingkat hubungan antara variabel keterlibatan dalam organisasi BEM $(\mathrm{X})$ dengan sikap demokratis mahasiswa disajikan pada tabel 5 berikut ini.

Tabel 5. Korelasi Antara Keterlibatan Organisasi (X) dengan Sikap Demokratis $\left(\mathrm{Y}_{2}\right)$

\begin{tabular}{lccc}
\hline \multicolumn{1}{c}{ Variabel } & $\mathrm{R}$ & $\mathrm{Sig}$ & $\mathrm{N}$ \\
\hline Keterlibatan dalam & 0,653 & 0,000 & 30 \\
organisasi BEM & & & \\
$\begin{array}{l}\text { (X) dan sikap } \\
\text { demokratis }\left(\mathrm{Y}_{2}\right)\end{array}$ & & & \\
\hline
\end{tabular}

Dari data pada tabel 5 diperoleh nilai signifikansi sebesar $0,000<\alpha(0,05)$ maka hipotesis kerja $\mathrm{H}_{1}$ diterima. Artinya terdapat hubungan yang signifikan antar keterlibatan dalam organisasi BEM (X) dengan sikap demokratis $\left(\mathrm{Y}_{2}\right)$. Hubungan ini ditunjukan dengan nilai korelasi sebesar 0,653 yang termauk dalam kategori kuat (0,60-799). 
Hasil Uji Hipotesis Ketiga yaitu Korelasi antara Keterampilan Berpikir Kritis (Y1) dengan Sikap Demokratis $\left(\mathrm{Y}_{2}\right)$.

Data hasil pengukuran tingkat hubungan antara variabel keterampilan berpikir kritis $\left(Y_{1}\right)$ dengan sikap demokratis $\left(Y_{2}\right)$ mahasiswa disajikan pada tabel 6 berikut ini.

Tabel 6. Korelasi antara Keterampilan Berpikir Kritis $\left(\mathrm{Y}_{1}\right)$ dengan Sikap Demokratis $\left(\mathrm{Y}_{2}\right)$

\begin{tabular}{lccc}
\hline \multicolumn{1}{c}{ Variabel } & $\mathrm{R}$ & $\mathrm{Sig}$ & $\mathrm{N}$ \\
\hline Keterampilan berpikir & 0,769 & 0,000 & 30 \\
Kritis $\left(\mathrm{Y}_{1}\right)$ dengan & & & \\
sikap demokratis $\left(\mathrm{Y}_{2}\right)$ & & & \\
\hline
\end{tabular}

Dari data pada tabel 6 diperoleh nilai signifikansi sebesar $0,000<\alpha(0,05)$ maka hipotesis kerja $\mathrm{H}_{1}$ diterima. Artinya terdapat hubungan yang signifikan antara keterampilan berpikir kritis $\left(\mathrm{Y}_{1}\right)$ dan sikap demokratis $\left(\mathrm{Y}_{2}\right)$.

Hubungan Keterlibatan dalam Organisasi BEM dengan Keterampilan Berpikir Kritis

Hasil analisis membuktikan bahwa, ada hubungan yang signifikan antara keterlibatan organisasi dengan keterampilan berpikir mahasiswa STKIP Weetebula. Hasil analisis korelasi membuktikan bahwa nilai signifikansi sebesar 0,000 , berarti nilai signifikansi lebih kecil dari 0,05 atau ( $\mathrm{sig}<0,05)$, artinya $\mathrm{H}_{0}$ ditolak dan $\mathrm{H}_{1}$ diterima. Hal ini menunjukan bahwa ada hubungan signifikan antara keterlibatan dalam organisasi BEM dengan keterampilan berpikir kritis mahasiswa STKIP Weetebula dengan koefesian sebesar 0,667 yang berarti besarnya hubungan termasuk dalam kategori kuat (0,60-799).

Hasil penelitian ini juga didukung oleh penelitian yang dilakukan oleh Putra (2010, p. 4) yang menyatakan ada hubungan kausal yang signifikan antara keterlibatan dalam organisasi dengan keterampilan berpikir kritis mahasiswa. Mahasiswa yang terlibat dalam organisasi melalui kegiatan-kegiatan yang diselenggarakan oleh organisasi akan membantu mahasiswa terampil dalam menggunakan pikirannya untuk menganalisis berbagai permasalahan yang dihadapinya dalam kehidupan bermasyarakat, berbangsa dan bernegara. Selanjutnya hasil penelitian Anggriawan (2014) menunjukan keterlibatan dalam orga- nisasi memiliki pengaruh terhadap kemampuan berpikir kreatif terutama dalam kemampuan memecahkan masalah yang dihadapi. Thompson $(2011$, p. 1) mengungkapkan bahwa keterampilan berpikir kritis adalah keterampilan yang paling penting bagi pemecahan masalah.

Hasil penelitian Montelongo (2002, pp. 61-62) yang berjudul Student Participation in College Student Organizations, terkait dengan keterlibatan mahasiswa dalam organisasi mahasiswa menyebutkan bahwa mahasiswa yang ikut terlibat dalam organisasi mahasiswa berpengaruh pada perkembangan kognitif atau proses intelektual yang lebih tinggi seperti berpikir kritis, pengetahuan akuisisi, sintesis, dan pengambilan keputusan, serta pengembangan afektif berupa sikap, nilai, aspirasi, dan kepribadian mahasiswa.

Pada era sekarang yang serba digital ini, dimana perubahan dalam bidang teknologi informasi dan komunikasi begitu cepat, sumber daya digital dan segala informasi dengan mudah dapat diakses kapan saja dan informasi dalam bentuk apa saja, bermanfaat atau tidak bermanfaat bagi mahasiswa (Wibowo, 2014, p. 89) tentunya membutuhkan keterampilan berpikir kritis agar mahasiswa tidak terjebak dalam pengaruh negatif yang merusak kehidupan berbangsa dan bernegara. Segala perangkat teknologi yang disajikan memungkinkan dipergunakan secara cerdas untuk kemaslatan pribadi, masyarakat, bangsa dan negara apabila mahasiswa memiliki keterampilan berpikir kritis. Mahasiswa yang memiliki keterampilan berpikir kritis merupakan Sumber Daya Manusia yang diharapkan pada abad ke-21 ini. Sumber Daya Manusia harapan Abad ke-21 yaitu Sumber Daya Manusia yang memiliki kapasitas sebagai berikut.

Kemampaun berpikir kritis dan pemecahan masalah (Critical-Thinking and Problem-Solving Skills)- mampu berfikir secara kritis, lateral, dan sistemik, terutama dalam konteks pemecahan masalah; (b) kemampuan berkomunikasi dan bekerjasama (Communication and Collaboration Skills) - mampu berkomunikasi dan berkolaborasi secara efektif dengan berbagai pihak; (c) kemampuan berkomunikasi dan bekerjasama (Communication and Collaboration Skills) - mampu berkomunikasi dan berkolaborasi secara efektif dengan berbagai pihak; (d) kemampuan mencipta dan membaharui (Creativity and Innovation Skills) 
- mampu mengembangkan kreativitas yang dimilikinya untuk menghasilkan berbagai terobosan yang inovatif; (e) literasi teknologi informasi dan komunikasi (Information and Communications Technology Literacy) mampu memanfaatkan teknologi. (f) kemampuan informasi dan literasi media (Information and Media Literacy Skills) - mampu memahami dan menggunakan berbagai media komunikasi untuk menyampaikan beragam gagasan dan melaksanakan aktivitas kolaborasi serta interaksi dengan beragam pihak (BSNP, 2010, pp. 44-45).

Hubungan Keterlibatan dalam Organisasi BEM dengan Sikap Demokratis

Hasil analisis membuktikan bahwa, ada hubungan yang signifikan antara keterlibatan dalam organisasi BEM dengan sikap demokratis mahasiswa STKIP Weetebula. Hasil analisis korelasi membuktikan bahwa nilai signifikansi sebesar 0,000 , berarti nilai signifikansi lebih kecil dari 0,05 atau (sig < $0,05)$, artinya $\mathrm{H}_{0}$ ditolak dan $\mathrm{H}_{1}$ diterima. Hal ini menunjukan bahwa ada hubungan signifikan antara keterlibatan organisasi dengan sikap demokratis mahasiswa STKIP Weetebula dengan koefesian sebesar 0,653 yang berarti besarnya hubungan termasuk dalam kategori kuat (0,60-799).

Hasil penelitian ini didukung oleh hasil penelitian yang dilakukan oleh (Diarsih, Pitoewas, \& Nurmalisa (2015) yang berjudul "Pengaruh Partisipasi Pada Kegiatan Organisasi Siswa Intra Sekolah Terhadap Sikap Demokratis Siswa" terhadap 59 responden siswa di SMA Negeri 1 Seputih Mataram Kabupaten Lampung Tengah mengungkapkan bahwa terdapat pengaruh signifikan dengan kategori keeratan tinggi antara keterlibatan dalam organisasi terhadap sikap demokratis.

Keterlibatan mahasiswa dalam kegiatan-kegiatan organisasi BEM seperti dalam rapat, diskusi adalah media yang dapat menumbuhkan lahirnya mahasiswa menjadi pemikir kritis. Bekoe, Kankam, Ayaaba, Eshun, \& Bordoh (2014, p. 52) dalam hasil penelitian yang berjudul "Teacher-Trainees' Sense of Efficacy in Students' Engagement, Instructional Practices and Classroom Management in Social Studies Lessons" menyarankan agar teknik keterlibatan siswa dalam bermain peran, diskusi, debat harus digunakan dalam pembelajaran Ilmu Sosial untuk membantu siswa menjadi pemikir kritis, pemecah masalah dan mampu menjadi generasi yang toleran.

\section{Hubungan Keterampilan Berpikir Kritis} dengan Sikap Demokratis

Hasil analisis membuktikan bahwa, ada hubungan yang signifikan antara keterampilan berpikir kritis dengan sikap demokratis mahasiswa STKIP Weetebula. Hasil analisis korelasi membuktikan bahwa nilai signifikansi sebesar 0,000 , berarti nilai signifikansi lebih kecil dari 0,05 atau (sig < 0,05), artinya $\mathrm{H}_{0}$ ditolak dan $\mathrm{H}_{1}$ diterima. Hal ini menunjukan bahwa ada hubungan signifikan antara keterampilan berpikir kritis dengan sikap demokratis mahasiswa STKIP Weetebula dengan koefesian sebesar 0,769 .

Berdasarkan hasil yang didapat pada perhitungan korelasi antara keterlibatan organisasi $(\mathrm{X})$ dengan keterampilan berpikir kritis $\left(\mathrm{Y}_{1}\right)$ adalah 0,667 . Perhitungan korelasi keterlibatan organisasi (X) dengan sikap demokratis $\left(\mathrm{Y}_{2}\right)$ adalah 0,653 . Perhitungan korelasi keterampilan berpikir kritis $\left(\mathrm{Y}_{1}\right)$ dengan sikap demokratis $\left(\mathrm{Y}_{2}\right)$ adalah 0,769 . Hasil ini artinya ada hubungan positif yang signifikan antara keterlibatan organisasi (X) dengan keterampilan berpikir kritis $\left(\mathrm{Y}_{1}\right)$, keterlibatan organisasi $(\mathrm{X})$ dengan sikap demokratis $\left(\mathrm{Y}_{2}\right)$, dan keterampilan berpikir kritis $\left(\mathrm{Y}_{1}\right)$ dengan sikap demokratis $\left(\mathrm{Y}_{2}\right)$.

Demikian dapat disimpulkan bahwa keterlibatan mahasiswa dalam organisasi mahasiswa seperti Badan Eksekutif Mahasiswa (BEM) sangat bermanfaat bagi pembinaan dan pengembangan keterampilan berpikir kritis mahasiswa, keterampilan berpikir kritis meliputi kemampuan mepresentasikan materi, mengajukan pertanyaan, menjawab pertanyaan, menarik kesimpulan. Selain keterampilan berpikir kritis, organisasi BEM dapat menjadi sarana terbinanya sikap demokratis mahasiswa. Hasil penelitian Hemafitria, Octavia, \& Novianty (2015, p. 180) mengungkapkan bahwa mahasiswa mendapatkan suatu binaan sikap demokrasi di dalam suatu organisasi mahasiswa.

Tingkat keterlibatan mahasiswa dalam kegiatan-kegiatan yang diselenggarakan oleh BEM memiliki korelasi dalam perkembangan keterampilan berpikir kritis dan sikap 
demokratis mahasiswa. Demikianpun perkembangan keterampilan berpikir kritis seorang dapat mendorong berkembangnya kesadaran akan keadaannya sebagai warga masyarakat/ warga negara yang memiliki naluri beserikat dan berkumpul dengan sesamanya. Hasil penelitian ten Dam \& Volman (2004, p. 395) mengungkapkan bahwa keterampilan berpikir kritis merupakan kompetensi yang penting dimiliki oleh seseorang untuk dapat berpartisipasi dalam kehidupan bermasyarakat. Pernyataan ten Dam \& Volman tersebut dapat diartikan bahwa seseorang yang memiliki keterampilan berpikir kritis akan mampu beradaptasi, terlibat dalam dinamika kehidupan masyarakat yang beraneka ragam suku, bahasa, bahkan pemikiran. Ia akan menjadi bagian dari anggota kelompok yang mampu bekerja sama dengan anggota kelompok masyarakat yang lain, memiliki sikap demokrtis seperti hidup toleran, percaya diri, tanggung jawab terhadap tugas kelompok dan mampu bermusyawarah untuk mengambil setiap keputusan yang bermanfaat dalam kehidupan bersama. Winataputra (2012, p. 195) mengungkapkan bahwa sikap demokratis dikalangan peserta didik yang merupakan warga negara muda mampu memberikan kontribusi yang berharga bagi peningkatan kualitas demokrasi dalam bermasyarakat, berbangsa dan bernegara Indonesia.

\section{Simpulan}

Berdasarkana hasil penelitian dan pembahasan, dari peneilitian ini dapat disimpulkan sebagai berikut. Pertama, hasil analisis koefisien korelasi product moment menunjukkan bahwa variabel keterlibatan dalam organisasi BEM mempunyai hubungan yang signifikan dengan keterampilan berpikir kritis pada mahasiswa STKIP Weetebula dengan nilai r-hitung sebesar 0,667 dan nilai signifikansi $0,000<0,05$. Oleh karena nilai signifikansi $0,000<0,05$, maka dapat dikatakan bahwa ada hubungan positif yang siginifikan antara keterlibatan organisasi BEM dengan keterampilan berpikir kritis. Mahasiswa yang terlibat dalam organisasi BEM mendapatkan maanfaat positif dengan berkembangnya keterampilan berkipir kritis mereka. Semakin aktif mahasiswa untuk terlibat dalam kegiatan organisasi semakin baik keterampilan berpikir kritis seorang mahasiswa. Keterampilan berpikir kritis tidak hanya bermanfaat untuk mengerjakan tugas-tugas kuliah tetapi juga bermanfaat ketika mereka terlibat dalam dinamika kehidupan bermasyarakat, berbangsa dan bernegara yang lebih nyata.

Kedua, hasil analisis koefisien korelasi product moment menunjukan bahwa variabel keterlibatan dalam organisasi BEM mempunyai hubungan yang signifikan dengan sikap demokratis pada mahasiswa STKIP Weetebula dengan nilai r-hitung sebesar 0,653 dan nilai signifikansi $0,000<0,05$. Oleh karena nilai signifikansi $0,000<0,05$, maka dapat dikatakan bahwa ada hubungan positif yang siginifikan antara keterlibatan organisasi BEM dengan sikap demokratis. Mahasiswa yang terlibat dalam organisasi BEM mendapatkan maanfaat positif dengan berkembangnya sikap demokratis mereka. Semakin aktif mahasiswa untuk terlibat dalam kegiatan organisasi semakin baik sikap demokratis seorang mahasiswa. Sikap demokratis sangat diperlukan bagi seorang mahasiswa, terlebih ketika mereka ikut terlibat sebagai warga negara aktif dalam kehidupan berbangsa dan bernegara.

Ketiga, hasil analisis koefisien korelasi product moment menunjukan bahwa variabel keterampilan berpikir kritis mempunyai hubungan yang signifikan dengan sikap demokratis pada mahasiswa STKIP Weetebula dengan nilai r-hitung sebesar 0,769 dan nilai signifikansi $0,000<0,05$. Oleh karena nilai signifikansi $0,000<0,05$, maka dapat dikatakan bahwa ada hubungan positif yang signifikan antara keterampilan berpikir kritis dengan sikap demokratis. Mahasiswa yang memiliki keterampilan berpikir kritis akan dengan mudah terlibat dalam proses diskusi yang melibatkan banyak orang dengan latar belakang suku, agama, ras, golongan dan pemikiran yang beraneka ragam. Semakin baik keterampilan berpikir kritis mahasiswa semakin baik pula sikap demokratis seorang mahasiswa.

Hasil penelitian tersebut menemukan bahwa keterlibatan mahasiswa dalam aktifitas organisasi yang tersedia di kampus mempunyai hubungan yang signifikan dengan berkembangnya keterampilan berpikir kritis dan berkembangnya sikap demokratis mahasiswa memberikan gambaran bahwa organisasi mahasiswa tidak dapat dikesampingkan kehadirannya dalam lingkungan kampus demi menunjang tercapainya visi dan misi sebuah 
perguruan tinggi. Berkaitan dengan itu maka penulis mengajukan beberapa saran yaitu sebagai berikut. Pertama, bagi mahasiswa agar mahasiswa memanfaatkan fasilitas berupa organisasi BEM yang ada di kampus sebagai media untuk mengembangkan keterampiran berpikir kritis, memanfaatkan organisasi BEM sebagai media untuk mengembangkan sikap demokratis seperti toleran terhadap berbagai perbedaan, dapat bekerja sama dengan orang lain untuk membangun kehidupan bersama yang lebih baik, selalu mengutamakan musyawarah dalam mengambil keputusan yang penting dalam kehidupan bersama, percaya diri dam memiliki tanggung jawab atas tugas yang diemban.

Kedua, bagi pihak kampus, agar pihak kampus memberikan dukungan kepada organisasi BEM baik berupa pendanaan maupun pendampingan kegiatan demi pengembangan keterampilan berpikir kritis dan sikap demokratis mahasiwa sehingga kelak lulusan yang dihasilkan oleh STKIP Weetebula adalah lulusan yang kritis dan memiliki sikap demokratis. Selain itu penulis juga memberikan saran agar kampus merancang pola pembinaan organisasi mahasiswa yang menarik sehingga organisasi BEM menjadi media ekstrakurikuler kampus yang menarik minat bagi mahasiswa untuk bergabung.

Ketiga, bagi peneliti selanjutnya, melakukan penelitian dibeberapa kampus khususnya yang ada di pulau Sumba dan Melakukan penelitian pengembangan model pendampingan organisasi mahasiswa dalam rangka pengembangan keterampilan berpikir kritis dan sikap demokratis mahasiswa.

\section{Daftar Pustaka}

Anggriawan, R. F. (2014). Pengaruh partisipasi kegiatan organisasi siswa intra sekolah terhadap berpikir kreatif dalam memecahkan masalah organisasi pada pengurus organisasi siswa intra sekolah di SMP Negeri 1 Gedangan. Skripsi. Universitas Islam Negeri Sunan Ampel Surabaya.

Arikunto, S. (2010). Prosedur penelitian: suatu pendekatan praktik. Jakarta: Rineka Cipta.

Bekoe, S. O., Kankam, B., Ayaaba, D. A., Eshun, I., \& Bordoh, A. (2014).
Teacher-trainees' sense of efficacy in students' engagement, instructional practices and classroom management in social studies lessons. American Journal of Psychology and Behavioral Sciences, 1(6), 52-60.

BSNP. (2010). Paradigma pendidikan nasional Abad-XXI. Jakarta: BSNP.

Depdiknas. Undang-Undang Nomor 20 Tahun 2003 tentang Sistem Pendidikan Nasional (2003). Jakarta.

Diarsih, K., Pitoewas, B., \& Nurmalisa, Y. (2015). Pengaruh partisipasi pada kegiatan organisasi siswa intra sekolah terhadap sikap demokratis siswa. Retrieved August 23, 2016, from http://download.portalgaruda.org/article. php? article $=328271 \&$ val $=7237 \&$ title $=P$ ENGARUH PARTISIPASI PADA KEGIATAN ORGANISASI SISWA INTRA SEKOLAH TERHADAP SIKAP DEMOKRATIS SISWA

Fadhilah, \& Nuraina. (2011). Penerapan demokrasi di lingkungan gerakan mahasiswa UNISMA Bekasi. Jurnal Kybernan, 2(2). Retrieved from http://ejournalunisma.net/ojs/index.php/kybernan/articl e/view/350/322

Fisher, A. (2009). Berpikir kritis: sebuah pengantar (Terjemahan). Jakarta: Erlangga.

Hemafitria, Octavia, E., \& Novianty, F. (2015). Implementasi sikap demokrasi dalam proses pembelajaran pendidikan kewarganegaraan pada mahasiswa IKIP PGRI Pontianak (studi deskriptif pada mahasiswa semester ii prodi PPKn tahun akademik 2014/2015). Sosial Horizon: Jurnal Pendidikan Sosial, 2(2), 173182. Retrieved from http://journal.ikippgriptk.ac.id/index.php /sosial/article/view/103

Kountur, R. (2009). Metodep penelitian untuk penulisan skripsi dan tesis. Jakarta: PPM.

Montelongo, R. (2002). Student participation in college student organizations: A review of literature. Journal of the Student Personnel Association at 
Indiana University, 50-63. Retrieved from

https://scholarworks.iu.edu/journals/inde x.php/jiuspa/article/view/4617

Perwita, A. A. B. (2005). Reformasi sektor keamanan demi demokrasi penanganan terorisme di Indonesia. Jurnal Ilmu Sosial Dan Ilmu Politik, 9(1), 45-70. https://doi.org/10.22146/JSP.11039

Presiden Republik Indonesia. Undang-Undang Republik Indonesia Nomor 12 Tahun 2012 tentang Pendidikan Tinggi (2012). Retrieved from http://diktis.kemenag.go.id/prodi/dokum en/UU-Nomor-12-Tahun-2012-ttgPendidikan-Tinggi.pdf

Putra, S. A. (2010). Hubungan kausal antara berorganisasi dan kemampuan berfikir kritis dengan prestasi belajar mahasiswa Program Studi Akuntansi Fakultas Keguruan dan Ilmu Pendidikan Universitas Muhammadiyah Surakarta angkatan 2009/2010. Retrieved November 18, 2015, from http://eprints.ums.ac.id/22657/21/11._N ASKAH_PUBLIKASI.pdf

Robinson, D. (2005). Menjadi penerjemah profesional (Terjemahan). London and New York: Routledge.

Samsuri. (2013). Paradigma pendidikan kewarganegaraan dalam kurikulum 2013. In Kuliah Umum Program Studi Pendidikan Pancasila dan Kewarganegaran. FKIP Universitas Ahmad Dahlan Yogyakarta.

Şanl1, Ö., \& Altun, M. (2015). The significance of establishing democratic education environment at schools. Journal of Educational and Instructional Studies in The World, 5(2). Retrieved from

http://www.wjeis.org/FileUpload/ds2172 32/File/01.onder_sanli.pdf

Schneider, V. (2012). Critical thinking in the elementary classroom: Problems and solutions. Educators Publishing Service. Retrieved from https://eps.schoolspecialty.com/EPS/med ia/Site-
Resources/Downloads/articles/Critical_T hinking-Schneider.pdf

Sudarman, M. (2013). Mengembangkan keterampilan berpikir kreatif. Jakarta: Rajawali Press.

Sugiyono. (2008). Metode penelitian kunatitatif kualitatif dan $R \& D$. Bandung: Alfabeta.

Sugiyono. (2010). Metode penelitian pendidikan, Pendekatan kuantitatif, kualitatif dan $R \& D$. Bandung: Alfabeta.

Sugiyono. (2012). Metode penelitian kuantitatif, kualitatif, dan $R \& D$. Bandung: Alfabeta.

Sugiyono. (2013). Metode penelitian kombinasi (Mixed Methods). Bandung: Alfabeta.

Sutrisno, M. (2013). Krisis peradaban. Yogyakarta: Kanisius.

ten Dam, G., \& Volman, M. (2004). Critical thinking as a citizenship competence: teaching strategies. Learning and Instruction, 14(4), 359-379. https://doi.org/10.1016/j.learninstruc.200 4.01 .005

The Critical Thinking Community. (2009). The pressing need for critical thinking. Retrieved December 29, 2015, from http://www.criticalthinking.org/pages/312-2009-the-pressing-need-for-criticalthinking/859

Thompson, C. (2011). Critical thinking across the curriculum: process over output. International Journal of Humanities and Social Science, 1(9). Retrieved from http://www.ijhssnet.com/journals/Vol._1 _No._9_Special_Issue_July_2011/1.pdf

Wibowo, A. (2014). Pendidikan karakter di perguruan tinggi. Jakarta: Pustaka Pelajar.

Winataputra, U. S. (2012). Pendidikan kewarganegaraan dalam perspektif pendidikan untuk mencerdaskan kehidupan bangsa (gagasan, instrumentasi, dan praksis). Bandung: Widya Aksara Press. 